\title{
Cladistics
}

\section{Phylogenetic analysis of the endemic New Caledonian cockroach Lauraesilpha. Testing competing hypotheses of diversification}

\author{
J. Murienne ${ }^{\mathrm{a}, \mathrm{b} *}$, R. Pellens ${ }^{\mathrm{b}}$, R. B. Budinoff ${ }^{\mathrm{c}}$, W. C. Wheeler ${ }^{\mathrm{c}}$ and P. Grandcolas ${ }^{\mathrm{b}}$ \\ ${ }^{a}$ Harvard University, Department of Organismic and Evolutionary Biology, 26 Oxford Street, Cambridge MA 02138 USA; ${ }^{b}$ UMR 5202 CNRS, \\ Département Systématique et Évolution, case 50, Muséum national d'Histoire naturelle, 45 rue Buffon, 75005 Paris, France; ${ }^{c}$ Division of Invertebrate \\ Zoology, American Museum of Natural History, 79th Street at Central Park West, New York, USA
}

Accepted 8 November 2007

\begin{abstract}
New Caledonia is a tropical hotspot of biodiversity with high rates of regional and local endemism. Despite offering an ideal setting to study the evolution of endemism, New Caledonia has received little attention compared with the other nearby hotspots, particularly New Zealand. Most studies of the Neocaledonian endemism have been carried out at the regional level, comparing the various groups and species present in New Caledonia but absent in neighboring territories. In addition, remarkably high short-range endemism has been documented among plants, lizard and invertebrates, although these have usually been done, lacking a phylogenetic perspective. Most studies of Neocaledonian endemism have referred to the geological Gondwanan antiquity of the island and its metalliferous soils derived from ultramafic rocks. Very old clades are thought to have been maintained in refugia and diversified on the metalliferous soils. The present study documents the pattern of diversification and establishment of short-range endemism in a phylogenetic context using the Neocaledonian cockroach genus Lauraesilpha. Mitochondrial and nuclear genes were sequenced to reconstruct phylogenetic relationships among the species of this genus. These relationships, in the light of the species distribution, do not support the hypothesis that species diversified via an adaptive radiation on metalliferous soils and are not consistent with areas of highest rainfall. Species of Lauraesilpha have similar altitudinal ranges and ecological habits and are short-range endemics on mountains. What our analysis did reveal was that closely related species are found on nearby or contiguous mountains, and thus these formations probably played the key role establishing short-range endemism (in association with recent climatic changes).
\end{abstract}

(C) The Willi Hennig Society 2008.

New Caledonia is widely recognized as a biodiversity hotspot (Myers et al., 2000). In addition to high species richness relative to its small size (about $19000 \mathrm{~km}^{2}$ ), it shows an exceptional level of endemism. Seventy-six percent of plant species (Lowry, 1998; Morat et al., 2001), $86 \%$ of reptiles (Bauer, 1999), and up to $100 \%$ of many invertebrate groups (Holloway, 1979; Chazeau, 1993; Haase and Bouchet, 1998; Najt and Grandcolas, 2002) are endemic. This island also harbors numerous endemics restricted to small areas ("short-range endemics"), either on peculiar soils or mountains. However, most of this short-range endemism has been documented from botanical inventories and taxonomic

\footnotetext{
*Corresponding author:

E-mail address: jmurienne@oeb.harvard.edu
}

revisions of invertebrate groups, and very few phylogenetic analyses have been undertaken to understand the pattern and timing of diversification of these Neocaledonian endemics (Good et al., 1997; Setoguchi et al., 1998; Pintaud and Jaffré, 2001; Murienne et al., 2005; Balke et al., 2006, 2007; Smith et al., 2007). Although little is known about the origins of local endemism, three main hypotheses have been advocated to explain them; the factors these hypotheses invoke lead to different predictions about any phylogenetic analysis of Neocaledonian endemics.

The first factor is soil diversity, specifically the metalliferous laterites derived from ultramafic rocks. New Caledonia was submerged and covered by the oceanic lithospheric mantle during the Eocene and a terrain of ultramafic rocks developed on the whole 
island during this period (Clarke et al., 1997; Aitchison et al., 1998; Cluzel et al., 2001; Rawling and Lister, 2002; Crawford et al., 2003). These rocks were later eroded and the pedogenesis gave birth to metalliferous and nickel-rich soils (Paris, 1981; Crawford et al., 2003). These soils have been often mentioned as an adaptive explanation for the occurrence of local endemism and richness in different groups of plants and animals (Holloway, 1979; Haase and Bouchet, 1998; Lowry, 1998; Bauer and Sadlier, 2000; Pintaud and Jaffré, 2001). Distributional and phylogenetic patterns resulting from this adaptation to metalliferous soils should typically substantiate radiations of species occurring on such soils with a smaller sister-group occurring on other soils, as currently assumed for Araucaria trees (Setoguchi et al., 1998).

A second causal factor that has been mentioned is the mountainous landscape and its orogeny. It can be invoked as a generator of endemism in conjunction with temperature and rainfall, as has been done with New Zealand's ranges (Trewick et al., 2000; Chinn and Gemmell, 2004). Interestingly, the Neocaledonian orogeny is much older than New Zealand's, dating back to the last major subduction events between 44 and 34 MYA. New Caledonian landscape is highly partitioned by several distinct groups of mountains that form a complex central chain, culminating in several places at more than $1600 \mathrm{~m}$ (Paris, 1981). If mountains played a role in the establishment of short-range endemism, species should be restricted to particular mountains and their phylogenetic relationships should reflect the geographic connections existing among the different parts of the central chain.

Climatic conditions vary considerably by elevation, western versus eastern slopes and other local particularities (Orstom, 1981). In this context, local mountainous areas presently receiving the highest rainfall have been seen as potential refuges for forest species during the driest periods of the Pleistocene (Pintaud et al., 2001). If climatic conditions have been more important in determining the endemism, an overlying relationship should be found between local climate and species relationships.

In order to better understand the pattern of diversification of the New Caledonian biota, we examined one local endemic radiation. The cockroach genus Lauraesilpha Grandcolas, 1997 (Insecta: Blattaria) belongs to the family Blattidae, subfamily Tryonicinae (Grandcolas, 1996, 1997), but see Klass and Meier (2006) for an alternative placement. Lauraesilpha cockroaches are small, flightless, wood-eaters, endemic to New Caledonian rainforests (Grandcolas, 1997; Grandcolas et al., 2002) and cockroaches is a useful group for studying endemism in New Zealand (Trewick, 2000; Chinn and Gemmell, 2004) and in New Caledonia (Pellens, 2004; Murienne et al., 2005). The number of Lauraesilpha species occurring without sympatry on an island only
$400 \mathrm{~km}$ long is remarkably high when compared with other tropical cockroach groups in which species have larger distributions (Grandcolas, 1994; Grandcolas and Pellens, 2008) but remarkably similar to observations of Neocaledonian species distributions in the cockroach genus Angustonicus (Pellens, 2004; Murienne et al., 2005). Lauraesilpha provides a good opportunity to study a Neocaledonian diversification with respect to metalliferous soils, mountains and climate. To understand the pattern of diversification in light of these three potentially causal factors, we sampled the genus Lauraesilpha on the New Caledonia mainland, and sequenced mitochondrial and nuclear genes. Using the resultant molecular phylogeny, we tested the following: (1) if Lauraesilpha diversified as an adaptive radiation on metalliferous soils, in which case we would find monophyletic groups of species on similar soils; (2) if species have diversified in relation to mountains, leading to species from the same mountain chains forming monophyletic groups independently of the substrate; or (3) if species have diversified mainly in climatic areas of highest rainfall, in which case species would form monophyletic groups according to rainfall-dependent refuges as hypothesized by Pintaud and Jaffré (2001).

\section{Materials and methods}

\section{Sampling}

Lauraesilpha is distributed across the Neocaledonian mainland (Grande Terre). Several species were found to be short-range endemics, but locally abundant where dead wood was in sufficient quantity for their xylophagous habits (Grandcolas et al., 2002). To assess their distribution patterns, Lauraesilpha were searched between 1994 and 2005 from 32 localities chosen to contrast soil types, mountains and climates (Table 1). Collecting locations, species distributional data, taxonomy and information on morphological diversity can be found in Grandcolas (1997), Grandcolas et al. (2002) and Murienne et al. (2008). The sampling strategy includes sites with different altitudes for the same broad locality in order to check species delimitation (specimens from the same mountain should form a monophyletic group). Only larvae have been collected from the mountain Mandjélia and are here referred to as "Lauraesilpha sp1". Also, as Mt Moné is part of the Koghis chain, the specimen from Mt Moné is not mapped independently from those of the Koghis mountains sensu stricto. Lauraesilpha angusta (Chopard, 1924) from Mt Ignambi has not been included in the molecular study as the specimens were too old to provide useful DNA. Our analysis thus includes all known Lauraesilpha species except one. Outgroups represent the large and worldwide family Blattidae: 
Table 1

Sampling localities and GenBank accession number of the specimens included in this study. Sampling has been made in 32 localities. Only those where Lauraesilpha was found are shown. Species on ultramafic soils are indicated in bold.

\begin{tabular}{|c|c|c|c|c|c|c|c|}
\hline Species & Locality & Latitude & Longitude & Altitude & 12S rRNA & 16S rRNA & $\mathrm{H} 3$ \\
\hline P. americana & Cosmopolitan & - & - & - & U17805 & U17806 & AF370816 \\
\hline M. soror & Australasia & - & - & - & U17793 & U17794 & EU486055 \\
\hline A. amieuensis & New Caledonia & -21.6100 & 166.7500 & - & AJ870995 & AJ870994 & EU486056 \\
\hline Tryonicus spl & New Caledonia & -20.5578 & 164.7916 & $330 \mathrm{~m}$ & EU486010 & EU486033 & EU486057 \\
\hline Tryonicus sp2 & New Caledonia & -20.3968 & 164.5322 & $800 \mathrm{~m}$ & EU486011 & EU486034 & EU486058 \\
\hline L. sp1 & Mandjélia & -20.4017 & 154.5236 & $685 \mathrm{~m}$ & EU486012 & EU486035 & EU486059 \\
\hline L. paniensis & Mt Panié & -20.5588 & 164.7846 & $550 \mathrm{~m}$ & EU486013 & EU486036 & EU486060 \\
\hline L. paniensis & Mt Panié & -20.5578 & 164.7916 & $330 \mathrm{~m}$ & EU486014 & EU486037 & EU486061 \\
\hline L. chazeaui & Aoupinié & -21.1565 & 165.3189 & $545 \mathrm{~m}$ & EU486015 & EU486038 & EU486062 \\
\hline L. chazeaui & Aoupinié & -21.1768 & 165.2691 & $1000 \mathrm{~m}$ & EU486016 & EU486039 & EU486063 \\
\hline L. koghiensis & Mt Moné & -22.1648 & 166.5111 & $850 \mathrm{~m}$ & EU486017 & EU486040 & EU486064 \\
\hline L. koghiensis & Mts Koghis & -22.1813 & 166.5115 & $500 \mathrm{~m}$ & EU486018 & EU486041 & EU486065 \\
\hline L. heteroclita & Rivière Bleue & - & - & $200 \mathrm{~m}$ & EU486019 & EU486042 & EU486066 \\
\hline L. vulcania & Pic Vulcain & -21.9167 & 166.3667 & $600 \mathrm{~m}$ & EU486020 & EU486043 & EU486067 \\
\hline L. antiqua & Mt Mou & - & - & $1200 \mathrm{~m}$ & EU486021 & EU486044 & EU486068 \\
\hline L. antiqua & Mt Mou & -22.0620 & 166.3444 & $1165 \mathrm{~m}$ & EU486022 & EU486045 & EU486069 \\
\hline L. antiqua & Mt Mou & -22.0752 & 166.3353 & $445 \mathrm{~m}$ & EU486023 & EU486046 & EU486070 \\
\hline L. do & Mt Do & -21.7491 & 166.0035 & $948 \mathrm{~m}$ & EU486024 & EU486047 & EU486071 \\
\hline L. dogniensis & Plateau de Dogny & - & - & $850 \mathrm{~m}$ & EU486025 & - & EU486072 \\
\hline L. dogniensis & Plateau de Dogny & -21.6289 & 165.8651 & $270 \mathrm{~m}$ & EU486026 & EU486048 & EU486073 \\
\hline L. mearetoi & Mé Aréto & -21.6041 & 165.774 & $710 \mathrm{~m}$ & EU486027 & EU486049 & EU486074 \\
\hline L. mearetoi & Mé Aréto & - & - & $680 \mathrm{~m}$ & EU486028 & EU486050 & EU486075 \\
\hline L. mearetoi & Mé Aréto & -21.5903 & 165.7829 & $520 \mathrm{~m}$ & EU486029 & EU486051 & - \\
\hline L. unio & Table Unio & -21.5647 & 165.7686 & $540 \mathrm{~m}$ & EU486030 & EU486052 & EU486076 \\
\hline L. unio & Table Unio & -21.5576 & 165.7717 & $850 \mathrm{~m}$ & EU486031 & EU486053 & EU486077 \\
\hline L. unio & Table Unio & -21.5576 & 165.7717 & $1000 \mathrm{~m}$ & EU486032 & EU486054 & EU486078 \\
\hline
\end{tabular}

three species endemic to New Caledonia (two species of Tryonicus and one of Angustonicus sampled at the same time), one species distributed in Oceania and Australia (Melanozosteria soror) and the cosmopolitan Periplaneta americana. The distribution of ultramafic rocks and corresponding metalliferous soils has been checked from the relevant and abundant literature (e.g., Latham et al., 1978; Orstom, 1981; Paris, 1981; Chevillotte et al., 2006), as well as for climate and orography from detailed maps (Orstom, 1981). Maps have been obtained using DIVA-GIS (Hijmans et al., 2002) with the geo 3az data (Generalized geology of Australia and New Zealand, US Geological Survey, Denver, CO, USA) and the worldclim data (Hijmans et al., 2005).

\section{DNA extraction, amplification and sequencing}

The molecular markers $12 \mathrm{~S}$ and $16 \mathrm{~S}$ rRNA, classically used for studying cockroaches and other insects (Kambhampati, 1995; Kambhampati et al., 1996; Murienne et al., 2005), and the H3 gene were utilized in this study in accordance with preliminary tests showing that this combination yielded the highest phylogenetic resolution.

A DNeasy Tissue Kit (Qiagen, Valencia, CA) was used for tissue lysis and DNA purification. Ready-ToGo polymerase chain reaction Beads (GE Healthcare, Piscataway, NJ) were used for amplifications. The 12Sai/12Sbi primers (Kambhampati, 1995) were used to amplify a fragment of approximately $420 \mathrm{bp}$ from the $12 \mathrm{~S}$ rRNA region of the mtDNA. The $16 \mathrm{SA} / 16 \mathrm{SB}$ primers (Kambhampati, 1995) were used to amplify a fragment of approximately $500 \mathrm{bp}$ from the 16S rRNA region of the mtDNA. The $\mathrm{H} 3 \mathrm{aF} / \mathrm{H} 3 \mathrm{aR}$ primers (Svenson and Whiting, 2004) were used to amplify a fragment of approximately $400 \mathrm{bp}$ from the $\mathrm{H} 3$ proteinencoding nuclear gene. Flanking regions were cropped in order to avoid missing data in the less clean regions. Each $25 \mu \mathrm{L}$ reaction contained $1 \mu \mathrm{L}$ of each $10 \mathrm{~mm}$ primer, $2 \mu \mathrm{L}$ of template and $21 \mu \mathrm{L}$ of water. Reaction mixtures were heated to $94{ }^{\circ} \mathrm{C}$ for $5 \mathrm{~min}$, followed by 35 cycles of $94{ }^{\circ} \mathrm{C}(15 \mathrm{~s}), 50{ }^{\circ} \mathrm{C}(15 \mathrm{~s})$ and $72{ }^{\circ} \mathrm{C}(15 \mathrm{~s})$, and then a final extension of $72{ }^{\circ} \mathrm{C}(7 \mathrm{~min})$ on MJ Research Peltier Thermal Cyclers (MJ Research Inc., Waltham, MA). Polymerase chain reaction products were purified using AMPure magnetic bead purification (Agencourt Bioscience Corp., Beverly, MA) on a Biomek NX robot (Beckman Coulter, Fullerton, CA). Amplification products were then sequenced in both directions. Each reaction mixture contained $1 \mu \mathrm{L}$ BigDye (Applied Biosystems), $1 \mu \mathrm{L}$ of $3.2 \mathrm{~mm}$ primer, $1 \mu \mathrm{L}$ BigDye Extender Buffer (Applied Biosystems) and $5 \mu \mathrm{L}$ of DNA template. Sequencing reactions ran for 25 cycles of $96{ }^{\circ} \mathrm{C}$ $(15 \mathrm{~s}), 50{ }^{\circ} \mathrm{C}(15 \mathrm{~s})$ and $60{ }^{\circ} \mathrm{C}(4 \mathrm{~min})$. Sequences were purified using CleanSeq magnetic bead purification (Agencourt Bioscience Corporation) on a Biomek NX robot (Beckman Coulter) to remove unincorporated 
primers and dyes. Products were re-suspended in $40 \mu \mathrm{L}$ of $0.5 \mathrm{~mm}$ EDTA and were electrophoresed in an ABI Prism 3730xl sequencer (Applied Biosystems).

\section{Phylogenetic analyses}

Phylogenetic analysis was carried out using Direct Optimization (Wheeler, 1996) with the software POY 3.0 (Wheeler et al., 2002). To maximize explanatory power (Kluge, 1989; Nixon and Carpenter, 1996), we analyzed all three loci simultaneously. 12S rRNA and 16S rRNA were treated under direct optimization and $\mathrm{H} 3$ treated as prealigned (after alignment according to the protein sequence). The analyses were performed using a subcluster of eight processors of the MNHN parallel cluster. The analysis began by generating three random addition sequences (RAS) per random replicate for 10 replicates. These 30 replicates were improved with tree bisection reconnection (TBR) branch swapping during the searches, an additional round of TBR branch swapping of all trees within $0.5 \%$ of the shortest tree(s) found per replicate (slop 5), 50 ratchet (Nixon, 1999) replicates (five rounds in each of the 10 replicates with ratchetpercent 10, ratchetseverity 3 and ratchettree 2), and treefusing (Goloboff, 1999) (fuselimit 100, fusemingroup 5, fusemaxtrees 100). In addition, all resulting trees within $1.0 \%$ of the shortest trees were examined in an additional round of TBR branch swapping (checkslop 10). Bootstrap frequencies (Felsenstein, 1985) and Bremer support (Bremer, 1988) were calculated with PAUP* (version 4.0b10; Swofford, 2002) and TreeRot (version 2; Sorenson, 1999) based on the resulting implied alignment. In order to assess the nodal stability (Giribet, 2003), we explored different parameter sets for gaps, transversion and transition (weights applied are indicated as XXX). In addition to equal weighting, we used 211, 221 and 421.

Static parsimony analyses were performed using PAUP* after alignment of the $12 \mathrm{~S}$ and $16 \mathrm{~S}$ with Clustal_X (Thompson et al., 1997). Gaps were treated as fifth state. Heuristic searches with RAS and TBR were followed by 1000 bootstrap replicates. For the ML analyses, the best-fit model was chosen using MraIc.pl (version 1.4; Nylander, 2004) and PHYML (Guindon and Gascuel, 2003) was then used with the fitting model with base frequencies estimated by maximum likelihood, $\mathrm{Ts} / \mathrm{Tv}$ ratio estimated, four substitution rate categories with the $\Gamma$ distribution parameter estimated. Results obtained for the different partitions are mentioned for the record.

\section{Results}

Lauraesilpha specimens were collected from abundant populations in dead wood at 12 of the 32 localities explored (Table 1). This distribution suggests that the genus is totally absent in dry sclerophyllous forests and "maquis" (a low and sparse vegetation with shrubs) and is present only in evergreen rainforests within the observed altitudinal range of $270-1165 \mathrm{~m}$. These evergreen rainforests typically consist of only angiosperm trees (even when heavily disturbed by humans, e.g., Plateau de Dogny), mixed forests with Araucariaceae and angiosperms (e.g., Mt Mou, $1200 \mathrm{~m}$ ), or heath forest fragments with a cover predominantly formed by Araucaria and Nothofagus trees (e.g., Mt Do). The analysis of the combined data set under direct optimization with Poy led to two equally parsimonious trees of 659 steps (consistency index, $\mathrm{CI}=0.74$ and retention index, $\mathrm{RI}=0.82$, consensus shown in Fig. 1). The general topology was not altered by variations of the parameter set even if few nodes were collapsed.

Our phylogeny strongly supports (bootstrap 100\%) the hypothesis that Lauraesilpha is monophyletic and sister to the genus Tryonicus (Fig. 1). Within Lauraesilpha, three main clades supported by very high bootstrap values are inferred: a clade from the central chain (Mt Aoupinié), which is sister to a clade consisting of a monophyletic group of species from northern chain of Panié (L. sp1 and L. paniensis) and another monophyletic group of species from all over the southern regions (all remaining species from Col d'Amieu to Rivière Bleue). Some species occurred on metalliferous soils only in the southern clade (Fig. 2) but not as a monophyletic group (five of eight species in the southern clade and five of 10-11 in the whole genus). If living on metalliferous soils is considered as a character state, its parsimonious optimization on the tree implies one origin ancestral to the southern clade and two reversals or one reversal followed by a second reversal toward the ancestral state in $L$. $d o$. In each region, specimens from the same mountains always clustered together regardless of elevation, and nearby or contiguous mountains harbored close relatives. For example, L. dogniensis, $L$. mearetoi, $L$. unio and $L$. do were close relatives and actually distributed over the same group of mountains (Fig. 3). The same pattern was found for species found between Mt Mou and Rivière Bleue, which were close geographically and formed a monophyletic group (Figs 1 and 3). Annual rainfall did not match the distribution of Lauraesilpha species, which are distributed in places of diverse climates within the tropical rainforests.

After alignment with Clustal_X, 12S rRNA, 16S rRNA and H3 genes had, respectively, 92, 114 and 49 parsimony informative characters, for a total length of 366,416 and 231 characters. The base composition was $35.7 \%$ A, $14.0 \% \mathrm{C}, 14.1 \% \mathrm{G}, 36.7 \% \mathrm{~T}$ for mitochondrial genes and $21.6 \% \mathrm{~A}, 31.3 \% \mathrm{C}, 26.2 \% \mathrm{G}, 20.9 \% \mathrm{~T}$ for the nuclear gene. As expected for insects, the sequences were AT rich for mitochondrial genes. In a 


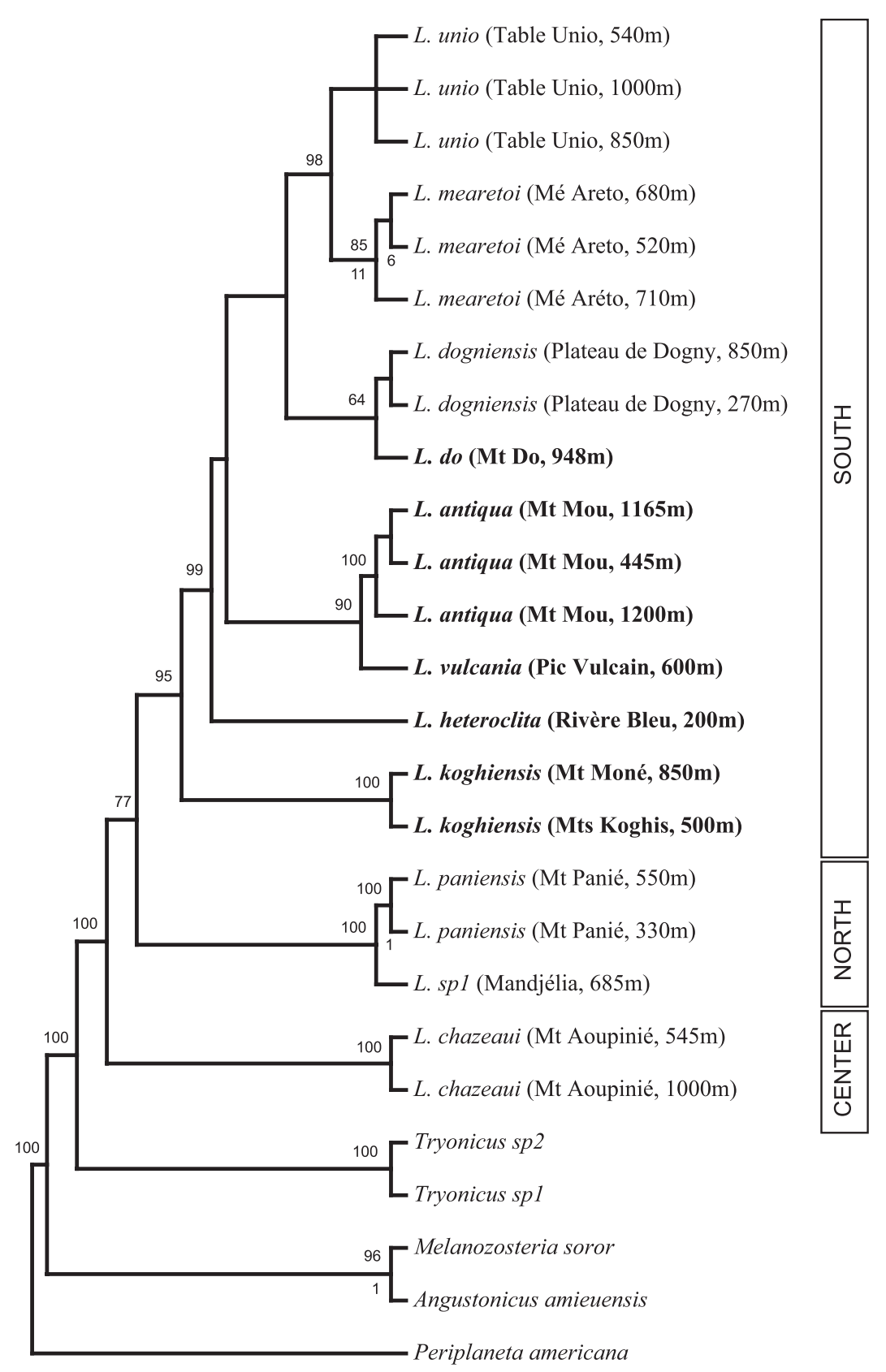

Fig. 1. Strict consensus of the two equally parsimonious trees obtained by POY with equal weighting. Bootstrap and Bremer values are indicated on nodes. Species occurring on ultramafic soils are indicated in bold. Distribution in New Caledonia (Grande Terre) is indicated in the sidebar.

static homology framework (alignment with CLUSTAL_X followed by tree-search with PAUP*) with equal weighting, the parsimony analysis led to one tree of 682 steps with $\mathrm{CI}=0.75$ and $\mathrm{RI}=0.82$, which was identical to one of the dynamic homology one (POY analysis), even with 23 extra steps. In this topology, the L. unio trichotomy was resolved with a sister group relationship between L. unio $550 \mathrm{~m}$ and L. unio $1000 \mathrm{~m}$. For the combined 12S rRNA, 16S rRNA and H3, the best-fit model was GTR $+\Gamma$. ML analysis resulted in a topology with $\ln \mathrm{L}=-4315.93$, which was identical with the parsimony analysis results. The final parameters estimates were as follows: base frequencies $\mathrm{A}=0.34$, $\mathrm{C}=0.17, \quad \mathrm{G}=0.16, \mathrm{~T}=0.33, \quad \alpha=0.277$. Separate analyses of the three included genes all gave the same general topology with three major clades (South, Center and North as specified in Fig. 1). However, mitochondrial and nuclear genes do not agree on the basal relationship of those clades. The nuclear gene favors a basal position of the northern clade, whereas 


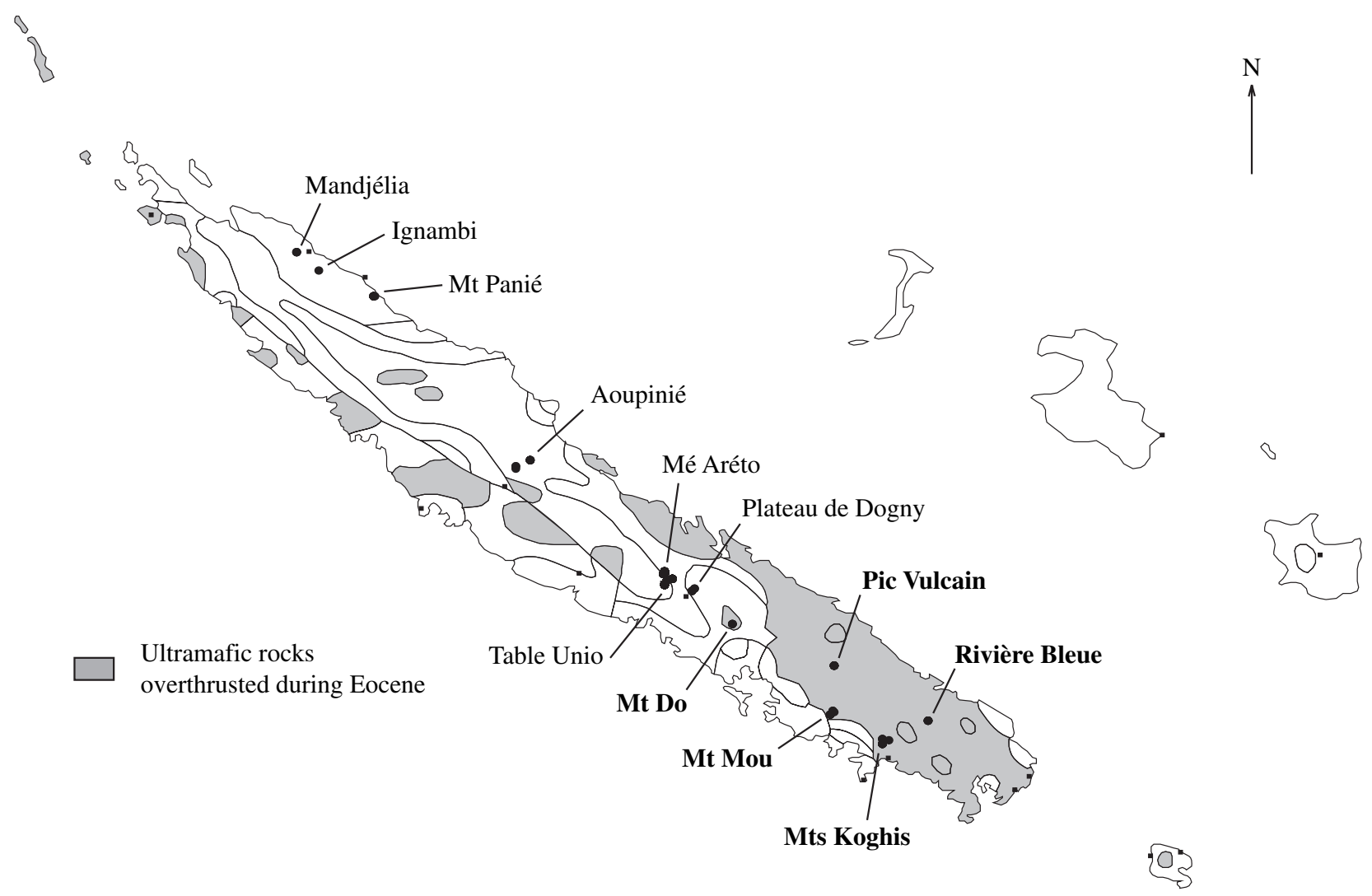

Fig. 2. Geological map showing the distribution of species and the location of ultramafic soils in New Caledonia. Circles represent site where species of Lauraesilpha have been found and squares sites where species have not been found. Locations on ultramafic soils are indicated in bold.

mitochondrial genes favor a basal position of the central clade. This could be attributed to conflicting lineage sorting in the earliest history of the genus or to the small number of informative characters for this particular node. We show the total tree resulting from the combined analysis of all available data (Fig. 1).

\section{Discussion}

\section{Importance of ultramafic rocks}

Metalliferous soils derived from ultramafic rocks represent only $1 \%$ of the emerged land on Earth (Broock, 1984) but cover about a third of New Caledonia. These rocks were formed during the obduction of the oceanic lithospheric mantle in the Eocene (Avias, 1967; Paris, 1981; Crawford et al., 2003) and at that time they covered the entire surface of New Caledonia. Owing to subsequent erosion, however, ultramafic rocks became restricted to the southern region and a number of small patches in the North. The combination of low nutrient and high nickel concentration in the ultramafic soils derived from these rocks provides a distinctive environment, which could have influenced biotic diversification (Jaffré, 1980). This environment was generally thought to have provided a refuge for "archaic" Gondwanan organisms, which would have otherwise disappeared through competition with more recent groups colonizing the island (Thorne, 1965; Morat et al., 1986), although this view has been challenged repeatedly (de Kok, 2002 for a review). The most spectacular example thought to support this hypothesis is found in the family Araucariaceae where 13 of the 19 species of Araucaria in the world are endemic to New Caledonia, 10 of which are found only on ultramafic soils (Setoguchi et al., 1998). Ultramafic soils may have also played a role in the diversification of the fauna, either directly through the influence of the soils or indirectly through the specialized vegetation. The influence of rock type on diversification may more strongly impact animals affected by the particular chemistry of metalliferous soil, via the water from rivers or streams, the plants or their dead organic matter for phytophagous or saprophagous animals, such as the xylophagous Lauraesilpha (Holloway, 1979; Bauer, 1989; Bauer and Sadlier, 2000; Boyd et al., 2006).

Such a scenario for the origin of the endemism in New Caledonia would be supported in a particular group of organisms if they had significantly more species 


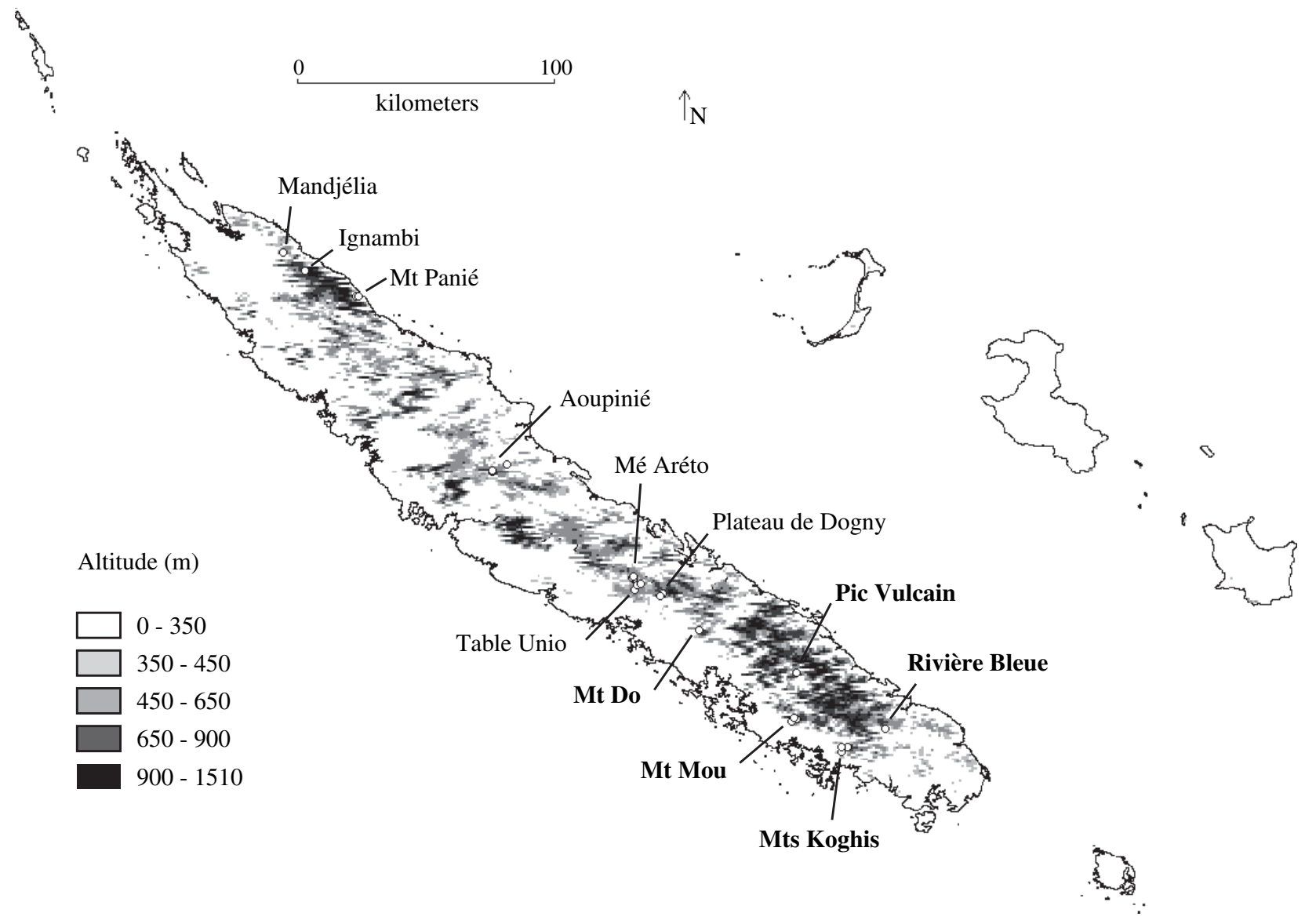

Fig. 3. Simplified topographic map of New Caledonia showing the distribution of species in relation to mountains. Species occurring on ultramafic soils are indicated in bold.

associated with ultramafic soils than with other soils, and the group found on ultramafic soils was monophyletic. This is not the case for Lauraesilpha. According to Fig. 1, the stem species that has acquired the habit of living on metalliferous soils has differentiated into five species having retained this habit. This could be interpreted as a radiation in the Southern clade, but considering the small number of species, it is impossible to test statistically if there has been a radiation on ultramafic soils. There is also evidence for several shifts between regions with or without metalliferous soils as if these changes do not have any adaptive significance. In light of the fact that only a limited number of species have radiated on ultramafic soils and that there has been multiple shifts between the soils, it is difficult to conclude that an adaptive radiation on metalliferous soils alone is responsible for the diversification of the genus.

Our results do not agree with previous generalizations about endemism in New Caledonia, which often refer to adaptive radiations on ultramafic soils, and they call for a re-examination of these earlier case studies. It is interesting that except for the exemplary case of
Araucaria (Setoguchi et al., 1998), other case studies on the relationships between endemism and ultramafic soils have been less decisive. For example, the phylogenetic analysis of two subtribes of palms had equivocal results vis-à-vis the ultramafic soils, and Pintaud and Jaffré (2001) concluded that some endemism on this substrate is also partly due to factors unrelated to the edaphic conditions. More generally, comparing the different vegetation on ultramafic rocks in the tropical Far East (Proctor, 2003), it appears that species richness and endemism are highly variable. Based on the phylogeny of Lauraesilpha, we show that some locally endemic species occurred on ultramafic rocks but that a major part of the diversification of the clade cannot be assumed to be related to these particular soils. As with certain groups of plants, other factors need to be invoked to fully explain the patterns of endemism in Lauraesilpha.

\section{Importance of mountains}

We have shown that specimens of Lauraesilpha from the same mountains always fall into the same clades. This is true for Mt Aoupinié $(545 \mathrm{~m}$ and $1000 \mathrm{~m}$ ), 
Mt Panié (330 $\mathrm{m}$ and $550 \mathrm{~m}$ ), Mt Mou (445 m, 1165m and $1200 \mathrm{~m}$ ), Plateau de Dogny (270 and $850 \mathrm{~m})$, Mé Aréto $(520 \mathrm{~m}, 680 \mathrm{~m}$ and $710 \mathrm{~m})$ and Table Unio $(540 \mathrm{~m}, 850 \mathrm{~m}$ and $1000 \mathrm{~m})$. This clustering by mountain occurs even for spatially close individuals that are on different peaks, such as those from Mé Aréto and Table Unio, which are only $5.5 \mathrm{~km}$ apart "as the crow flies". Several closely related species (forming a sistergroup relationship) appear to have exclusive connections (see Fig. 3). This was true for Mandjélia-Mt Panié, Plateau de Dogny-Mt Do and Pic Vulcain-Mt Mou. However, the phylogenetic position of some species does not fit a scenario where the mountains played such a role in the diversification of the clade. For example, we expected species from Pic Vulcain and Mt Mou to cluster with species from Mt Koghis and Rivière Bleue. However, the Pic Vulcain-Mt Mou clade is more closely related to species from which they are separated by much lower elevation. It appears that if we look at a global scale, we cannot conclude that mountains and the shape of the landscape have played a major role in the diversification of the genus. On the other hand, if we look at a local scale, mountains seem to have played a part in the establishment of microendemism.

Microendemism is frequently associated with mountains (Kruckeberg and Rabinowitz, 1985). Mountains play an important and complex part as the association of altitude with climatic variations can cause diversification (Trewick et al., 2000; Calsbeek et al., 2003; Chinn and Gemmell, 2004). In particular, climatic variations are supposed to promote diversification by allopatric speciation related to niche conservatism (Wiens, 2004). In this case, an ancestral species is displaced to higher altitudes by the expansion of drier climates at lower altitudes (e.g., Hope and Pask, 1998) and the populations become separated on each mountain (provided that the ecological preferences of the species did not change). After separation, isolation in several descendant species occurred on each mountain. This scenario is favored when related species on different mountains show the same ecological range in terms of altitudinal distribution and environment use. Phylogenetic and distributional patterns of Lauraesilpha species have therefore led us to conclude that the mountains have played a part in their establishment of microendemism. Given the ecological homogeneity of the genus and the absence of an obvious relationship with present climatic parameters, the origin of microendemism can be attributed to speciation by isolation on different mountains following previous climatic variations. At present, Lauraesilpha species are no longer geographically separated on mountains as they occur from peaks to low elevations and must be assumed to have speciated during previous isolation event. A more refined sampling along mountain chains and a population genetic approach could allow testing of this hypothesis. If past drying of lowland habitats resulted in allopatric speciation with various populations of Lauraesilpha isolated on mountain top refugia, we should be able to detect range expansion of populations (from high elevation to low elevation) in the different species. This approach could also be informative about the identity of Lauraesilpha sp1.

\section{Importance of climatic refuges}

Allopatric speciation could have also occurred with respect to climatic variations leading to forest fragmentation and the creation of forest refuges (Haffer, 1969; Bush, 1994). In this later scenario, hypothesized by Pintaud et al. (2001) for Neocaledonian palms, shortrange endemic species are supposed to occur only in those limited areas with the highest rainfalls. The genus Lauraesilpha occurs too widely in New Caledonia to provide support for such a scenario and the monophyletic groups of species shown by our analysis do not correspond to particular climatic areas.

\section{Conclusions}

The situation exposed here is very similar to that described for the cockroach genus Angustonicus in New Caledonia (Murienne et al., 2005) and the Neocaledonian cricket genus Agnotecous (Desutter-Grandcolas and Robillard, 2006). These genera similarly include short-range endemic species in tropical rainforests with allopatric distributions and no obvious ecological differences. In the case of Angustonicus, the recent age of the diversification was assessed by its basal split between species from the New Caledonian mainland and the more recent coraline Loyalty Islands. These previous studies of Neocaledonian insects, as well as the present study, contrast with molecular results obtained from other animals such as geckos (Rhacodactylus), the diversification of which took place 15 million years ago and resulted in much wider and partly sympatric distributions (Good et al., 1997; Bauer et al., 2004).

Even if Lauraesilpha diversification is similar in many aspects to the situation of the cockroach as analyzed by Chinn and Gemmell (2004) in New Zealand, they are not entirely analogous. Chinn and Gemmell (2004) studied the radiation of 10 species of Celatoblatta in South Island, New Zealand. They observed a relationship between ecological change and phylogenetic differentiation that was interpreted as a consequence of recent mountain building. These results differ from the present study where Lauraesilpha species seem to have remained with a stable but large ecological range. The environment is different as well, for New Zealand has experienced both strong cooling and a recent orogenesis (Trewick et al., 2000), which could have shaped the cockroach diversification. 
New Caledonia has often been portrayed as a "museum" of biodiversity, housing species of old lineages and low extinction rates (Stebbins, 1974), particularly plants (see Lowry, 1998 for a review). Accordingly, short-range endemism and local diversification were most often assumed to result from the diversity of metalliferous soils, mountains and/or climatic heterogeneity (Holloway, 1979; Morat et al., 1986; Chazeau, 1993; Haase and Bouchet, 1998; Lowry, 1998; Setoguchi et al., 1998; Bauer and Sadlier, 2000). Many different organisms other than plants are also known to have distributions correlated to particular soils, such as butterflies, mollusks and lizards (Holloway, 1979; Haase and Bouchet, 1998; Bauer and Sadlier, 2000). Clearly, Lauraesilpha cockroaches do not appear to have diversified according to soils or climatic refuges and mountains seems to have only played a part on a very local scale.

\section{Acknowledgments}

We are grateful to Direction des ressources naturelles of Service de l'Environnement de la Province Sud, to Service de l'environnement, Direction du Développement Economique et de l'Environnement, Province Nord, and to H. Jourdan (IRD Nouméa) for permitting and helping kindly with field work. C. A. D'Haese provided many helps with the MNHN cluster. We would like to thank the four anonymous referees for greatly improving the clarity of the manuscript and R. Clouse, G. Goodbody-Gringley, P. Sharma, F. Legendre, E. Guilbert, M. Gaudeul and J-F. Silvain for their careful reading of the manuscript. Fieldwork was funded by the Programme Pluriformation "Structure et évolution des ecosystèmes" (Ministry of Education and Research, Muséum national d'Histoire naturelle). Part of the laboratory work was funded by the Annette Kade Graduate Student Fellowship from the American Museum of Natural History to JM. RP has a CNPq (Brazil) Post Doctoral Grant (number 200983/2004-0). JM is presently a Lavoisier Fellow of the French Ministry of Foreign Affairs.

\section{References}

Aitchison, J.C., Ireland, T.R., Clarke, G.L., Cluzel, D., Davis, A.M., Meffre, S., 1998. Regional implications of U/Pb SHRIMP age constraints on the tectonic evolution of New Caledonia. Tectonophysics 299, 333-343.

Avias, J., 1967. Overthrust structure of the main ultrabasic New Caledonian massives. Tectonophysics 4, 531-541.

Balke, M., Wewalka, G., Alarie, Y., Ribera, I., 2006. Molecular phylogeny of Pacific Island Colymbetinae: radiation of New Caledonian and Fijian species (Coleoptera, Dytiscidae). Zool. Scr. 36, 173-200.
Balke, M., Pons, J., Ribera, I., Sagata, K., Vogler, A.P., 2007. Infrequent and unidirectional colonization of hyperdiverse Papuadytes diving beetles in New Caledonia and New Guinea. Mol. Phylogenet. Evol. 42, 505-516.

Bauer, A.M., 1989. Reptiles and the biogeographic interpretation of New Caledonia. Tuatara 30, 39-50.

Bauer, A.M., 1999. Tropical island herpetofauna: origin, current diversity, and conservation. In: The Terrestrial Reptiles of New Caledonia: the Origin and Evolution of a Highly Endemic Herpetofauna, pp. 3-25. Elsevier, Amsterdam.

Bauer, A.M., Sadlier, R.A., 2000. The Herpetofauna of New Caledonia. Society for the Study of Amphibians and Reptiles, Ithaca.

Bauer, A.M., Jackman, T.R., Kiebish, M., 2004. Molecular systematics of the New Caledonian geckos Rhacodactylus and Eurydactylodes (Squamata: Diplodactylidae). N. Z. J. Zool. 31, 99-111.

Boyd, R.S., Wall, M.A., Jaffré, T., 2006. Nickel levels in arthropods associated with Ni hyperaccumulator plants from an ultramafic site in New Caledonia. Insect Sci. 13, 271-277.

Bremer, K., 1988. The limits of amino-acid sequence data in angiosperm phylogenetic reconstruction. Evolution 42, 795-803.

Broock, R., 1984. General introduction. In: Dudley, T.R. (Ed.), Serpentine and its Vegetation, a Multidisciplinary Approach, Vol. 1: Ecology, Phytogeography and Physiology Series, pp. 5-7. Dioscorides Press, Portland, OR.

Bush, M.B., 1994. Amazonian speciation - A necessarily complex model. J. Biogeogr. 21, 5-17.

Calsbeek, R., Thompson, J.N., Richardson, J.E., 2003. Patterns of molecular evolution and diversification in a biodiversity hotspot: the California Floristic Province. Mol. Ecol. 12, 1021-1029.

Chazeau, J., 1993. Research on New Caledonian terrestrial fauna: achievements and prospects. Biodiv. Lett. 1, 123-129.

Chevillotte, V., Chardon, D., Beauvais, A., Maurizot, P., Colin, F., 2006. Long-term tropical morphogenesis of New Caledonia (Southwest Pacific): importance of positive epeirogeny and climate change. Geomorphology 81, 361-375.

Chinn, W.G., Gemmell, N.J., 2004. Adaptive radiation within New Zealand endemic species of the cockroach genus Celatoblatta Johns (Blattidae): a response to Plio-Pleistocene mountain building and climate change. Mol. Ecol. 13, 1507-1518.

Clarke, G.L., Aitchison, J.C., Cluzel, D., 1997. Eclogites and Blueschists of the Pam Peninsula, NE New Caledonia: a Reappraisal. J. Petrol. 37, 843-876.

Cluzel, D., Aitchison, J.C., Picard, C., 2001. Tectonic accretion and underplating of mafic terranes in the Late Eocene intraoceanic fore-arc of New Caledonia (Southwest Pacific): geodynamic implications. Tectonophysics 340, 23-59.

Crawford, A.J., Meffre, S., Symonds. P.A., 2003. Chapter 25: 120-0 Ma tectonic evolution of the southwest Pacific and analogous geological evolution of the 600-220 Ma Tasman Fold Belt system. Geol. Soc. Aust. Spec. Publ. 22, 377-397.

Desutter-Grandcolas, L., Robillard, T., 2006. Phylogenetic systematics and evolution of Agnotecous, New Caledonia (Orthoptera: Grylloidea, Eneopteridae). Syst. Entomol. 31, 65-92.

Felsenstein, J., 1985. Confidence limits on phylogenies: An approach using the bootstrap. Evolution 39, 783-791.

Giribet, G., 2003. Stability in phylogenetic formulations and its relationship to nodal support. Syst. Biol. 52, 554-564.

Goloboff, P.A., 1999. Analyzing large data sets in reasonable times: solutions for composite optima. Cladistics 15, 415-428.

Good, D.A., Bauer, A.M., Sadlier, R.A., 1997. Allozyme evidence for the phylogeny of giant New Caledonian geckos (Squamata: Diplodactylidae: Rhacodactylus), with comments on the status of R. leachianus henkeli. Aust. Zool. 45, 317-330.

Grandcolas, P., 1994. Les Blattes de la forêt tropicale de Guyane Française: structure du peuplement (Insecta, Dictyoptera, Blattaria). Bull. Soc. Zool. Fr. 119, 59-67. 
Grandcolas, P., 1996. The phylogeny of cockroach families: a cladistic appraisal of morpho-anatomical data. Can. J. Zool. 74, 508-527.

Grandcolas, P., 1997. Systématique phylogénétique de la sous-famille des Tryonicinae (Dictyoptera, Blattaria, Blattidae). In: Najt, J., Matile, L. (Eds.), Zoologia Neocaledonica. Mém. Mus. Natl. Hist. Nat., 171, 91-124.

Grandcolas, P., Pellens, R., 2008. Blattodea. In: Rafael, J.A., Rodrigues de Melo, G.A., Barros de Carvalho, C.J., Casari, S.A (Eds.), Insetos do Brasil: Diversidade e Taxonomia. INPA, Manaus, Brazil, in press.

Grandcolas, P., Bellés, X., Piulachs, M.-D., D'Haese, C., 2002. Le genre Lauraesilpha Grandcolas, 1997: nouvelles espèces, endémisme, séquences d'ARN ribosomique et caractères d'appartenance aux Blattidae (Insectes, Dictyoptères, Blattidae, Tryonicinae). In: Najt, J., Grandcolas, P. (Eds.), Zoologia Neocaledonica 5. Systématique et Endémisme En Nouvelle-Calédonie. Mém. Mus. Nat. Hist. Nat., 187, 117-131.

Guindon, S., Gascuel, O., 2003. A simple, fast, and accurate algorithm to estimate large phylogenies by maximum likelihood. Syst. Biol. 52, 696-704.

Haase, M., Bouchet, P., 1998. Radiation of crenobiontic gastropods on an ancient continental island: the Hemistomia-clade in New Caledonia (Gastropoda: Hydrobiidae). Hydrobiologia 367, 43129.

Haffer, J., 1969. Speciation in Amazonian forest birds. Science 165, $131-137$.

Hijmans, R.J., Cruz, M., Rojas, E., 2002. Computer tools for spatial analysis of plant genetic resource data: 1. DIVA-GIS. Pl. Genet. Res. Newslett. 127, 15-19.

Hijmans, R.J.K., Cameron, S.E., Parra, J.L., Jones, P.G., Jarvis, A., 2005. Very high resolution interpolated climate surfaces for global land areas. Int. J. Climatol. 25, 1965-1978.

Holloway, J.D., 1979. A Survey of the Lepidoptera, Biogeography and Ecology of New Caledonia. Series Entomologica 15. Dr W. Junk, The Hague, Netherlands.

Hope, G., Pask, J., 1998. Tropical vegetational change in the late Pleistocene of New Caledonia. Palaeogeogr. Palaeoclimatol., Palaeoecol. 142, 1-21.

Jaffré, T., 1980. Etude Ecologique du Peuplement Végétal des Sols Dérivés de Roches Ultrabasiques en Nouvelle-Calédonie. Coll. Trav. Doc. ORSTOM 124, 1-274.

Kambhampati, S., 1995. A phylogeny of cockroaches and related insects based on DNA sequence of mitochondrial ribosomal RNA genes. Proc. Natl Acad. Sci. USA 92, 2017-2020.

Kambhampati, S., Luykx, P., Nalepa, C.A., 1996. Evidence for sibling species in Cryptocercus punctulatus, the wood roach, from variation in mitochondrial DNA and karyotype. Heredity 76, 485-496.

Klass, K.-D., Meier, R., 2006. A phylogenetic analysis of Dictyoptera (Insecta) based on morphological characters. Entomol. Abh. 63, 3-50.

Kluge, A.G., 1989. A concern for the evidence and a phylogenetic hypothesis for relationships among Epicrates. Syst. Zool. 38, 1-25.

de Kok, R., 2002. Are plant adaptations to growing on serpentine soil rare or common? A few case studies from New Caledonia. Adansonia 24, 229-238.

Kruckeberg, A.R., Rabinowitz, D., 1985. Biological aspects of endemism in higher plants. Annu. Rev. Ecol. Syst. 16, 447-479.

Latham, M., Quantin, P., Aubert, G., 1978. Étude des Sols de la Nouvelle-Calédonie. Nouvel essai sur la classification, la caractérisation, la pédogenèse et les aptitudes des sols de NouvelleCalédonie. Notice explicative no. 78. Office de la Rercherche Scientifique et Technique Outre Mer (ORSTOM), Paris.

Lowry, P.P., 1998. Diversity, endemism, and extinction in the flora of New Caledonia, a review. In: Peng, C.I., Lowry, I.I.P.P. (Eds.), Proceedings of the International Symposium on Rare. Threatened and Endangered Floras of Asia and the Pacific Rim, pp. 181-206. Academia Sinica, Taipei, Taiwan.
Morat, P., Veillon, J.-M., Mackee, H.S., 1986. Floristic relationships of New Caledonian rainforest phanerogams. Teleopea 2, 631-679.

Morat, P., Jaffré, T., Veillon, J.-M., 2001. The flora of New Caledonia's calcareous substrates. Adansonia 23, 109-127.

Murienne, J., Grandcolas, P., Piulachs, M.-D., Bellés, X., D'Haese, C., Legendre, F., Pellens, R., Guilbert, E., 2005. Evolution on a shaky piece of Gondwana: is local endemism recent in New Caledonia? Cladistics 21, 2-7.

Murienne, J., Pellens, R., Grandcolas, P., 2008. Short-range endemism in New Caledonia. New species and distribution in the genus Lauraesilpha. In: Grandcolas, P. (Ed.) Zoologia Neocaledonica 6, Systematics and Biodiversity in New Caledonia. Mém. Mus. Nat. Hist. Nat., 196, in press.

Myers, N., Mittermeier, R.A., Mittermeier, C.G., da Fonseca, G.A., Kent, J., 2000. Biodiversity hotspots for conservation priorities. Nature 403, 853-858.

Najt, J., Grandcolas, P. (Eds.), 2002. Zoologia Neocaledonica 5. Systématique et endémisme en Nouvelle-Calédonie, Mém. Mus. Nat. Hist. Nat., 187. Publications Scientifiques du Muséum.

Nixon, K.C., 1999. The parsimony ratchet, a new method for rapid parsimony analysis. Cladistics 15, 407-414.

Nixon, K.C., Carpenter, J.M., 1996. On simultaneous analysis. Cladistics 12, 221-241.

Nylander, J.A.A., 2004. MrAIC.pl, version 1.4. Program distributed by the author, Evolutionary Biology Centre, Uppsala University.

Orstom, 1981. Atlas de la Nouvelle-Calédonie et Dépendances, chap. Eléments généraux du climat Pl. 11. Editions de l'Office de la Recherche Scientifique et Technique Outre-Mer, Paris.

Paris, J.P., 1981. Géologie de la Nouvelle-Calédonie. Un essai de synthèse (Mémoire pour servir notice explicative à la carte géologique de la Nouvelle-Calédonie à l'échelle du 1/200000, avec 2 cartes). Mém. BRGM 113, 1-278.

Pellens, R., 2004. Nouvelles espèces d'Angustonicus Grandcolas, 1997 (Insecta, Dictyoptera, Blattaria, Tryonicinae) et endémisme du genre en Nouvelle-Calédonie. Zoosystema 26, 307-314.

Pintaud, J.C., Jaffré, T., 2001. Patterns of diversity in palms on ultramafic rocks in New Caledonia. South Afr. J. Sci. 97, 548-550.

Pintaud, J.C., Jaffré, T., Puig, H., 2001. Chorology of New Caledonian palms and possible evidence of Pleistocene rain forest refugia. C.R. Acad. Sci. Séries III Life Sci. 324, 453-463.

Proctor, J., 2003. Vegetation and soil and plant chemistry on ultramafic rocks in the tropical Far East. Perspect. Plant Ecol. Evol. Syst. 6, 105-124.

Rawling, T.J., Lister, G.S., 2002. Large-scale structure of the eclogiteblueschist belt of New Caledonia. J. Struct. Geol. 24, 1239-1258.

Setoguchi, H., Asakawa Osawa, T., Pintaud, J.C., Jaffré, T., Veillon, J.-M., 1998. Phylogenetic relationships within Araucariaceae based on rbcL gene sequences. Am. J. Bot. 92, 316-329.

Smith, S.A., Sadlier, R.A., Bauer, A.M., Austin, C.C., Jackman, T., 2007. Molecular phylogeny of the scincid lizards of New Caledonia and adjacent areas: Evidence for a single origin of the endemic skinks of Tasmantis. Mol. Phylogenet. Evol. 43, 1151-1166.

Sorenson, M.D., 1999. TreeRot, ver. 2. Boston University, Boston, MA.

Stebbins, G.L., 1974. Flowering Plants, Evolution Above the Species Level. Harvard University Press, Cambridge, MA.

Svenson, G.J., Whiting, M.F., 2004. Phylogeny of Mantodea based on molecular data: evolution of a charismatic predator. Syst. Entomol. 29, 359-370.

Swofford, D.L., 2002. PAUP*: Phylogenetic Analysis Using Parsimony and Other Methods, version 4.0b10. Sinauer, Sunderland, MA.

Thompson, J., Gibson, T., Plewniak, F., Jeanmougin, F., Higgins, D., 1997. The clustal_x windows interface: Flexible strategies for multiple sequence alignment aided by quality analysis tools. Nucleic Acids Res. 25, 4876-4882.

Thorne, R.F., 1965. Floristic relationships of New Caledonia. Univ. Iowa Stud. Nat. Hist. 21, 1-14. 
Trewick, S.A., 2000. Molecular evidence for dispersal rather than vicariance as the origin of flightless insect species on the Chatham Islands, New Zealand. J. Biogeogr. 27, 1189-1200.

Trewick, S.A., Wallis, G.P., Morgan-Richards, M., 2000. Phylogeographical pattern correlates with Pliocene mountain building in the alpine scree weta (Orthoptera, Anostostomatidae). Mol. Ecol. 9, 657-666.
Wheeler, W.C., 1996. Optimization alignment: The end of multiple sequence alignment in phylogenetics? Cladistics 12, 1-9.

Wheeler, W.C., Gladstein, D., De Laet, J., 2002. POY, Version 3.0. Available from ftp.amnh.org/pub.molecular/poy/.

Wiens, J.J., 2004. Speciation and ecology revisited: phylogenetic niche conservatism and the origin of species. Evolution 58, 193 197. 